\title{
Nosematosis of white silkworm and measures to combat with it
}

\author{
$D A$ Ismatullaeva ${ }^{1, *}$ and $S h$ Ruzmatov $^{1}$ \\ ${ }^{1}$ Tashkent State Agrarian University, University str., 2, Tashkent province, Uzbekistan, 100140
}

\begin{abstract}
This article presents the results of studies on the treatment of silkworm grena, slightly infected with nosematosis. As a result of treatment of grena with antibiotics and their combinations, a significant increase in the revitalization of grena and a decrease in the extensiveness of infection with nosematosis of revitalizing caterpillars is observed. It has been established that antibiotic chemicals, especially in combinations, contribute to the disinfection of grains from infectious diseases, in particular from nosematosis, and thereby improve the quality of silkworm grains. Which, in turn, helps to prevent the occurrence of diseases on the pedigree and industrial feedings of the silkworm
\end{abstract}

\section{Introduction}

The study of infectious diseases, widespread in the silk-growing regions of the world, including in Uzbekistan, and causing great economic damage to the silk industry, at different times were studied by scientists from different countries [1, 3, 13-21]. Despite the significant amount of research carried out, many issues in this industry remain relevant and need to be addressed.

Currently, in the world to study the causes of the emergence of epizootics of infections in the feeding of the silkworm in a number of priority areas, research is being carried out, including: the study of the epizootic situation, the species composition of microorganisms and the role of environmental factors in their occurrence, an express diagnostic method has been developed, the production method has been improved, free from the causative agent of nosematosis $[2,8]$.

The body's resistance to disease is due to its natural physiological protective properties, the decisive role among which belongs to phagocytosis, which is performed by cells of hemolymph, pericardium, and fatty body. Natural immunity in insects depends on many factors: the age of the insect, temperature, and food [4, 5].

As a result of studying the epizootology of the disease, it was found that the causative agent of nosematosis, Nosema bombycis N., is a parasite with a wide range of hosts, capable of developing in 9 species of natural insects [1]. This allowed the development of a recommendation to prevent infection of the silkworm with nosematosis from wild insects.

The search for prophylactic nozemacids, active against the spore form of the pathogen, showed that from the numerous arsenals of tested chemicals, an organic acid with tanning

* Corresponding author: d.a.ismatullaeva@yandex.com 
properties deserves a positive assessment. Its nosemacid activity is characterized by the compaction of the spore envelope, as a result of which the polar tube with the embryo does not eject and the spores lose their viability. A new disinfectant is recommended for production to replace formalin [6-9].

As known, the success of the fight against any infectious disease primarily depends on the use of various methods of prevention, including those involving the use of chemicals. In sericulture, disinfection of feeding rooms and equipment is used as one of the preventive methods [10]. Various chemicals are used for disinfection. With their help, disinfection is carried out in various ways - by spraying, spraying (dry powders), and gassing (evaporation of funds or using ready-made aerosol preparations). Known use in silkworm breeding such chemicals as chloramine, monochloramine, calcium hypochlorite, sodium hypochlorite, the drug AAS, "Glac", formalin, estosteril-1. For the purpose of gasification of industrial premises for the destruction of bacteria and fungi, bleach is shown in combination with glutaraldehyde or ammonium nitrate. The recommended disinfectants are acceptable for silkworm breeding according to the criteria of the duration of the residual effect on the surface of the disinfected object, stability in the external environment, low depletion of the disinfecting action and relatively low cost $[11,12]$.

However, all of them are more effective against bacterial and fungal diseases and are ineffective against especially dangerous diseases and, in particular, against nosematosis. In past years, the Uzbek Research Institute of Sericulture also conducted research to find preparations of disinfectants that actively act on the spore form of the causative agent of nosematosis. It was found that dibasic organic oxalic acid has the highest nozemacid activity. It was recommended for implementation and was introduced for 2 years in the breeding zone of the Namangan ditch plant [3-5].

The relationship of microsporidia with insects at the cell level and at the organismal level has been studied in great detail and described in a number of works [14-17].

At the same time, in the host-parasitic relationship of the silkworm with the causative agent of pebrin, the biomechanism of the development of pathology is poorly studied.

This gap in the study of the host-parasitic relationship of microsporidia with beneficial insects was to some extent filled by our studies carried out in 1993-1995 on a silkworm infected with nosematosis [1]. The activity of nonspecific esterases and proteolytic activity of hemolymph of silkworm caterpillars in the development of nosematous invasion were studied. In insect organisms, esterases are directly involved in the metabolism of juvenile hormones and their analogs, which are responsible for the processes of metamorphism [4, $5,8]$. The participation of proteolytic enzymes in the regulation of processes that change under the influence of nosematous invasion.

\section{Materials and methods}

For the study, we used an infected grena (eggs), caterpillars-revivals of the silkworm breed Ipakchi 2, and purified cultures of spores of the causative agent Nosema bombycis $\mathrm{N}$. obtained from infected caterpillars.

In the spring, 10 days before the start of incubation, we take out the greenhouse from the refrigerator, keep it for 2 days in preparation (at $\mathrm{t}=+15-16^{\circ} \mathrm{C}$ ) and then subject it to treatment in aqueous solutions of the test preparations. The treatment was carried out by immersing the grena in the prepared drug solutions for 2 hours. Grena is carefully rubbed with hands so that it is evenly wetted and does not contain lumps. Then the drug solutions are drained, the grena is laid out on filter paper for drying [3]. After drying the greenhouse, 100 pieces are counted from each variant in 3 repetitions. Each replication is placed in a paper bag, which indicates the variant number and replication. A variant in which the grena is kept for 2 hours in ordinary water served as a control for the experiment. 
Then the bags with green bean are placed for incubation in a thermostat at a temperature of $25^{\circ} \mathrm{C}$ and a relative humidity of $75-80 \%$. After $7-9$ days, registration of caterpillar emergence from the grena began. For this purpose, the number of grains from which the caterpillars did not come out is counted in each bag. The rate of exit of caterpillars from the groome is estimated as a percentage. Then the released caterpillars, after 7-10 days, are subjected to microscopic analysis to determine the residual infestation. Each caterpillar is microscoped separately. Microanalysis is carried out in a conventional light microscope using a phase contrast device. At least 50 fields of vision are visible in each preparation.

\section{Results and discussion}

Based on the prerequisites available in the literature, the task was set to determine the optimal doses of pharmaceutical chemicals and their combinations for the treatment of nosematosis at the stages of grena. For this, thorough research has been carried out.

The characteristics of the biological activity of the tested agents were assessed according to two main indicators - the release of caterpillars from the groin and the presence of infestation. Table 1 shows the results of an experiment on the revitalization of a grena slightly infected with nosematosis after treatment with antibiotics and their combinations.

Table 1. The liveliness of the test material's grins (2019-2020).

\begin{tabular}{|c|c|c|c|c|c|}
\hline \multirow[t]{2}{*}{$\#$} & \multirow[t]{2}{*}{$\begin{array}{l}\text { Drug name } \\
\text { dose, } \\
\text { mg or million units }\end{array}$} & \multicolumn{2}{|c|}{$\begin{array}{l}\text { The liveliness of the grene } \\
\text { (compare from } 3 \\
\text { replicates), } \%\end{array}$} & \multirow{2}{*}{$\begin{array}{c}\begin{array}{c}\text { Difference in } \\
\text { comparison } \\
\text { with control, \% }\end{array} \\
\text { d }\end{array}$} & \multirow{2}{*}{$\begin{array}{c}\begin{array}{c}\text { The } \\
\text { reliability } \\
\text { of the } \\
\text { difference }\end{array} \\
\text { Pd } \\
\end{array}$} \\
\hline & & $\bar{X}_{ \pm \mathbf{S}} \bar{x}$ & $\mathrm{Cv}$ & & \\
\hline \multirow{2}{*}{1} & Metronidazole $250 \mathrm{mg}$ & $83.6 \pm 7.5$ & 18.2 & 7.6 & 0.999 \\
\hline & Metronidazole $500 \mathrm{mg}$ & $89.3 \pm 9.7$ & 10.5 & 13.3 & 0.999 \\
\hline \multirow[t]{2}{*}{2} & Sinurol 0.6 million units & $85.3 \pm 7.7$ & 11.3 & 9.3 & 0.999 \\
\hline & Sinurol 1.2 million units & $88.6 \pm 7.3$ & 12.0 & 12.6 & 0.999 \\
\hline \multirow{2}{*}{3} & Ciprofloxacin $250 \mathrm{mg}$ & $86.6 \pm 5.6$ & 12.6 & 10.6 & 0.999 \\
\hline & Ciprofloxacin $500 \mathrm{mg}$ & $88.6 \pm 6.0$ & 14.8 & 12.6 & 0.999 \\
\hline 4 & $\begin{array}{l}\text { Sinurol } 1.2 \text { million units }+ \\
\text { Metronidazole } 500 \mathrm{mg}\end{array}$ & $91.3 \pm 7.5$ & 15.0 & 15.3 & 0.999 \\
\hline 5 & $\begin{array}{l}\text { Metronidazole } 500 \mathrm{mg}+ \\
\text { Ciprofloxacin } 500 \mathrm{mg}\end{array}$ & $92.0 \pm 5.8$ & 12.0 & 16.0 & 0.999 \\
\hline 6 & Control (water) & $76.0 \pm 2.8$ & 4.1 & - & - \\
\hline 7 & Control (dry) & $79.7 \pm 1.9$ & 3.6 & - & - \\
\hline
\end{tabular}

Butylcaptax and droppa inhibit the rate of electron transfer and oxidative phospholation in the liver mitochondria of the mother and fetus. These disorders are most pronounced in case of poisoning with butylcaptax on the 19th day of pregnancy.

The study of the state of the oxidase systems of the mitochondrial membranes of the liver of pregnant rats and embryos shows that butylcaptax and droppa reduce the activities of NAD.H-oxidase, succinate oxidase, and cytochrome with oxidase at all times of 
inoculation. The most strongly inhibited NAD.H-oxidase activity of mitochondria in pregnant rats and embryos in case of butylcaptax poisoning. Butylcaptax leads to a deeper inhibition of the rate of electron transfer in various fragments of the respiratory chain of liver mitochondria. The most profound inhibition is observed in the NAD.H-oxidase branch during poisoning with butylcaptax on the 19th day of pregnancy.

Thus, the pesticides butylcaptax and droppa cause ultrastructural and, therefore, functional changes in the subcellular components of hepatocytes in pregnant rats and embryos. These changes reduce the protective and adaptive capabilities of the whole organism.

As can be seen, according to the data in Table 1, in the experimental variants the revival of the grena ranged from $83.6-92.0 \%$, and in the control variant, where the grène was kept in water, it was $79.7 \%$. When grena is treated with antibiotics in a single variant, an increase in the percentage of revival of grena is observed in comparison with control by 7.6-12.6\%. The best result is determined in variants with combinations of chemicals 91.3$92.0 \%$, which contributed to an increase in the revival of grena by $15.3-16.0 \%$ in comparison with the control. For clarity, a graphical representation of the percentage of revitalization of a grena treated daily with antiseptic chemicals is given (Figure 1).

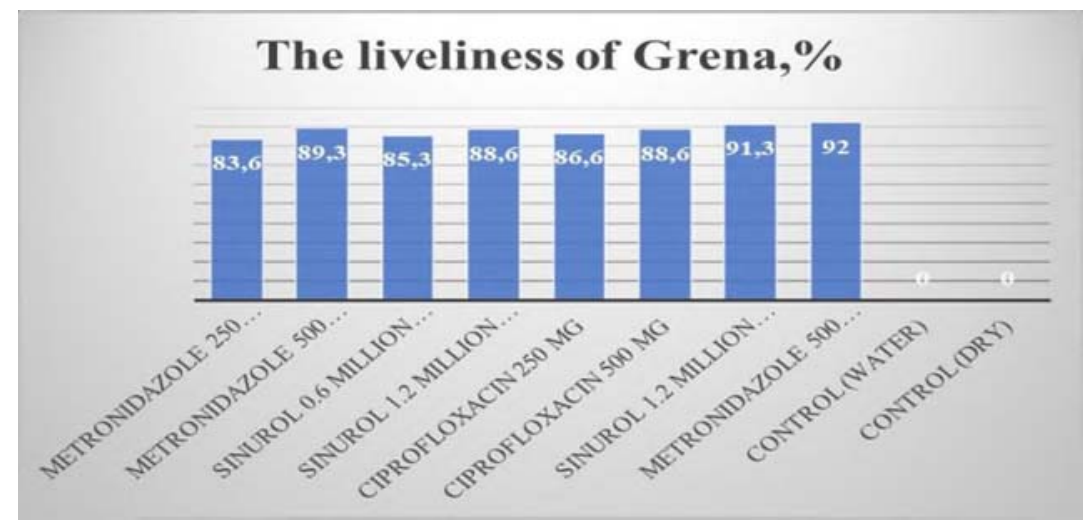

Fig. 1. Percentage of revitalization of Grena after treatment with chemicals.

As can be seen in the figure, in all experimental variants, the yield of caterpillars is higher than the control variant, which indicates a favorable effect of the chemicals on the embryo inside the body (eggs.)

After determining the percentage of revitalization of the grena, the caterpillars were subjected to microscopic analysis to determine the residual infection with Nosematosis. Table 2 shows data on the infection of revived caterpillars with nosematosis. 
Table 2. Infection of the experimental material with the causative agent of Nozema bombycis N. in comparison with the control.

\begin{tabular}{|c|c|c|c|c|c|c|}
\hline \multirow[t]{2}{*}{ \# } & \multirow{2}{*}{ Drug name } & \multirow{2}{*}{ 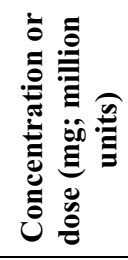 } & \multicolumn{2}{|c|}{$\begin{array}{l}\text { Infestation of } \\
\text { caterpillars of } \\
\text { revivals, } \%\end{array}$} & \multirow{2}{*}{ 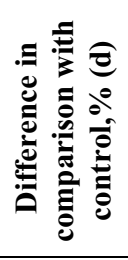 } & \multirow{2}{*}{ 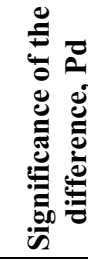 } \\
\hline & & & $\bar{X}_{ \pm \mathbf{S}} \bar{x}$ & $\mathbf{C v}$ & & \\
\hline \multirow[t]{2}{*}{1} & Metronidazole & 250 & $17.7 \pm 2.6$ & 1.7 & 11.9 & 0.999 \\
\hline & Metronidazole & 500 & $12.8 \pm 0.8$ & 3.5 & 16.8 & 0.999 \\
\hline \multirow{2}{*}{2} & Ciprofloxacin & 250 & $16.6 \pm 0.6$ & 5.6 & 13.0 & 0.999 \\
\hline & Ciprofloxacin & 500 & $13.2 \pm 0.5$ & 6.0 & 16.4 & 0.999 \\
\hline \multirow{2}{*}{3} & Sinurol & 0.6 & $14.6 \pm 0.6$ & 13.0 & 15.0 & 0.999 \\
\hline & Sinurol & 1.2 & $13.3 \pm 2.3$ & 16.1 & 16.3 & 0.999 \\
\hline 4 & $\begin{array}{c}\text { Sinurol + } \\
\text { Metronidazole }\end{array}$ & $\begin{array}{l}1.2 \\
500\end{array}$ & $10.8 \pm 7.5$ & 15.0 & 18.8 & 0.999 \\
\hline 5 & $\begin{array}{c}\text { Metronidazole + } \\
\text { Ciprofloxacin }\end{array}$ & by 500 & $9.5 \pm 6.0$ & 14.8 & 20.1 & 0.999 \\
\hline 6 & Control (water) & - & $29.6 \pm 0.8$ & 3.9 & - & - \\
\hline 7 & Control (dry) & - & $29.9 \pm 1.2$ & 4.7 & - & - \\
\hline
\end{tabular}

As evidenced by the data in the table, in all experimental variants, the infection with nosematosis in comparison with the control variant varies from 9.5 to $17.7 \%$, respectively. The difference (d) in comparison with the control was expressed only in a decrease in the contamination of the experimental material, and it was $11.9-20.1 \%$. This indicates that all tested antibiotic preparations were to some extent effective in reducing the infection with Nosema in the experimental material.

The best result is observed in variants with combinations of Metronidazole $500 \mathrm{mg}+$ Sinurol 1.2 million units and Metronidazole $500 \mathrm{mg}$ with Ciprofloxacin $500 \mathrm{mg}$, where the infection rate is $9.5-10.8 \%$, against the control (water) - $29.6 \%$. That is, a significant decrease in the extensiveness of infection with nosematosis is determined by $18.8-20.1$ absolute percent.

Thus, we have established that antibiotic preparations of a wide spectrum of action, especially in combinations, contribute to the disinfection of gren from infectious diseases, in particular from nosematosis, and thereby improve the quality of silkworm grena. This, in turn, helps to prevent the occurrence of diseases on the pedigree and industrial feedings of the silkworm.

\section{Conclusions}

The results obtained agree with the literature data indicating that antibiotics have an inhibitory effect on parasitic protozoa, which include the causative agent of silkworm nosematosis. A decrease in the extensiveness of infection of grena with nosematosis after treatment with these agents can be due, on the one hand, to the destructive effect of the tested agents on the vegetative stages of the pathogen's development and, on the other hand, to the inhibitory effect of the agents on the process of sporulation of the pathogen. 
The greatest decrease in the extent of infection is observed in variants where Metronidazole (500 mg) with Sinurol (1.2 million units) and Ciprofloxacin (500 mg) by $18.8-20.1 \%$. Metronidazole was found to be more effective against nosematosis than other antibiotics tested due to its antiprotozoal and antimicrobial properties. The mechanism of action consists in the biochemical reduction of the 5-nitro group by intracellular transport proteins of anaerobic microorganisms and protozoa.

In the complex of Metronidazole with Sinurol $1.2 \mathrm{mln}$ or with Ciprofloxacin $500 \mathrm{mg}$ complement each other, which contribute to an even greater increase in the effectiveness of anti-eruption, antibacterial, antimicrobial action.

Thus, the treatment of Nosema-infected Grena before incubation with pharmaceutical preparations that have a wide spectrum of antibacterial action, suppressing the growth and development of most gram-positive and gram-negative microorganisms, contributed to a significant decrease in the infection with Nosematosis in comparison with the control.

A test of antibiotics on green soil contaminated with Nosema showed that they have anti-nozema effect. In the future, it is planned to re-test two combinations of Metronidazole with Sinurol and Ciprofloxacin, also supplemented with vitamins and minerals in order to create a complex pharmaceutical preparation that simultaneously stimulates the development of silkworm and disinfects green from various infections.

\section{References}

1. E. A. Akhmedov, J. Agrarian Russia, 4, 41-44 (2009)

2. N. Teshaev, B. Mamadaliyev, A. Ibragimov, S. Khasanov, InterCarto. InterGIS, 26(3), 324-333 (2020)

3. E. A. Garafutdinova, D. A. Ismatullaeva, L. F. Kashkarova, Uzbek Biological Journal, 1-2, 3-5 (2008)

4. V. A. Golovko, I. A. Kirichenko, E. V. Chmutova, Silk, 5-6, 15-16 (1994)

5. P. Mirkhamidova, D. Tuychieva, D. Bobokhonova, M. Parpieva, European Journal of Molecular \& Clinical Medicine, 7(3), 37-57 (2020)

6. A. Jumanov, S. Khasanov, A. Tabayev, G. Goziev, U. Uzbekov, E. Malikov, IOP Conf. Ser.: Earth Environ. Sci., 614(1), 012150 (2020)

7. S. Isaev, S. Khasanov, Y. Ashirov, T. Karabaeva, A. Gofirov, E3S Web Conf., 244, 02012 (2021)

8. I. V. Issi, Parasitology, 31, 121-143 (1983)

9. D. A. Ismatullaeva, L. F. Kashkarova, In Proceedings of the scientific-practical conference "Scientific basis of the development of silkworm breeding in Uzbekistan", 73-79 (2001)

10. S. Isaev, S. Khasanov, Y. Ashirov, A. Gofirov, T. Karabaeva, E3S Web Conf., 244, 02047 (2021)

11. N. Sabitova, O. Ruzikulova, I. Aslanov, E3S Web Conf., 227, 03003 (2021)

12. Y. Ten, R. Oymatov, K. Khayitov, G. Saydalieva, U. Nulloev, I. Nematov, E3S Web Conf., 227, 04004 (2021)

13. L. F. Kashkarova, SH. R. Umarov, Silkworm diseases, diagnosis and prevention, 78-81 (2008)

14. B. Sh. Matyakubov, Z. J. Mamatkulov, R. K. Oymatov, U. N. Komilov, G. E. Eshchanova, InterCarto. InterGIS, 26, 229-239 (2020) 
15. SH. R. Madyarov, A. SH. Khamraev, D. O. Otarbaev, Uzbek Biological Journal, 6, 58-61 (2007)

16. N. Ch. Namozov, D. A. Kodirova, M. I. Usmonova, International journal of scientific \& technology research, 9(03), 5491-5493 (2020)

17. K. V. Ananthalakshmi, T. Fujiwara, R. K. Datta, Indian J. Sericult., 33, 146-148 (1994)

18. S. A. Bhat, B. Nataraju, Int. J. Ind. Entomol., 9, 265-267 (2007)

19. S. Chakrabarti, B. Manna, Int. J. Entomol, 17, 173-180 (2008)

20. Z. Mamatkulov, E. Safarov, R. Oymatov, I. Abdurahmanov, M. Rajapbaev, E3S Web Conf., 227, 03001 (2021)

21. W. Li, V. Kapalunenko, Y. Wang, V. Dimchev, Open Journal of Animal Sciences, 3, 169-173 (2009) 